
PIDE Working Papers

No. 2020:22

\title{
Oil Price Volatility and Stock Returns: Evidence from Three Oil-price Wars
}

\author{
Mushtaq Hussain Khan \\ University of Azad Jammu \& Kashmir, Muzaffarabad. \\ Junaid Ahmed \\ Pakistan Institute of Development Economics, Islamabad. \\ and \\ Mazhar Mughal \\ Pau Business School, France.
}

\section{PAKISTAN INSTITUTE OF DEVELOPMENT ECONOMICS} ISLAMABAD 
Editorial Committee

Lubna Hasan

Saima Bashir

Junaid Ahmed

Disclaimer: Copyrights to this PIDE Working Paper remain with the author(s). The author(s) may publish the paper, in part or whole, in any journal of their choice.

Pakistan Institute of Development Economics

Islamabad, Pakistan

E-mail: publications@ pide.org.pk

Website: http://www.pide.org.pk

Fax: $\quad+92-51-9248065$

Designed, composed, and finished at the Publications Division, PIDE. 


\section{O N T E N T S}

Page

Abstract $\quad$ V

1. Introduction 1

2. Related Literature 4

3. Data and Methodology 5

3.1. Data 5

3.2. Estimation Strategy

4. Findings 11

4.1. Volatility Models 11

4.2. VAR Models 14

5. Conclusions and Policy Implications 18

$\begin{array}{ll}\text { Appendix } & 19\end{array}$

$\begin{array}{ll}\text { References } & 20\end{array}$

\section{List of Tables}

Table 1. Summary Statistics $\quad 6$

Table 2. Structural Break Points-Bai-Perron Test 7

Table 3. Johansen and Joselius Cointegration Tests: Trace Statistics (Full Sample) 9

Table 4. Johansen and Joselius Cointegration Tests: Max-Eigen Value $\begin{array}{ll}\text { Statistics (Full Sample) } & 10\end{array}$

Table 5. Volatility Models $\quad 12$

\section{List of Figures}

Figure 1. Examples of Volatility Clustering for Brent Oil 2

Figure 2. Examples of Volatility Clustering for WTI Oil 3

Figure 3. Generalised Impulse-response Functions of Oil and Gas Stock Returns to Oil Price Shocks During Oil-price War I (1997-1999) 15

Figure 4. Generalised Impulse-response Functions of Oil and Gas Stock Returns to Oil Price Shocks During Oil-price War II (2014-2016)

Figure 5. Generalised Impulse-response Functions of Oil and Gas Stock Returns to Oil Price Shocks During Oil-price War III (2020-Onward) 16

$\begin{array}{ll}\text { Figure 6. Granger Causality Test } & 17\end{array}$ 


\begin{abstract}
This study examines how crude oil price volatility affected the stock returns of major global oil and gas corporations during three major oil-price wars that took place between October 1991 and June 2020. Episodes considered include the 1998 Saudi Arabia-Venezuela war, the 2014-16 conflict and the 2020 Saudi Arabia - Russia war in a time of unprecedented crisis caused by the COVID-19 pandemic. Our findings reveal a significant evidence for volatility persistence and leverage effects in oil price during the three oil-price wars. These findings are consistent for WTI as well as Brent crude oil specifications. Though the persistence of volatility is similar to that of the previous two oilprice wars, the 2020 Saudi Arabia-Russia oil-price war has higher volatility spikes than the previous two wars. Besides, oil price shocks have a significant and positive effect on the returns of oil and gas companies. These findings provide information on how volatility in global oil prices is also sensitive to irregular events such as price wars between oil producers. This information can be important for economic agents contemplating shorter hedges by managing risks during times of high volatility.
\end{abstract}

JEL Classifications: C32; G12; Q40; Q43

Keywords: Crude Oil; Oil and Gas Corporations; Oil-price Wars; Stock Returns; Volatility 


\section{INTRODUCTION}

Studies in energy economics have extensively documented the extreme volatility in the crude oil prices over the past decades as a result of extreme and irregular events. These include, on the one hand, extreme events such as geopolitical tensions and wars (e.g. Gulf War, 1990), economic crises (e.g. Mexico 1994; the East Asia crisis 1997; Argentina 2001), financial crises (e.g. Long Term Capital Management (LTCM) Russia 1998; Mortgage-backed-securities US 2008) or major terrorist attacks (e.g. 9/11), and on the other hand, irregular events such as hurricanes, OPEC production policy changes, disruption in oil production or supply due to worker strikes etc. Literature suggests a strong association between oil price volatility and stock market returns.

However, the debate is still ongoing and empirical evidence so far on the strength and direction of association is inconclusive. Some studies (e.g. Jones and Kaul 1996; Sadorsky 1999; Driesprong et al. 2008; Diaz et al. 2016; Joo and Park 2017; Xiao et al. 2018; Westerlund and Sharma 2019) pointed to a negative relationship, whereas others reported a positive association (Narayan and Narayan, 2010; Gupta, 2016; Diaz and Perez de Gracia, 2017; Luo and Qin, 2017; Wen et al. 2019) or even evidence for no significant relationship (e.g. Chen et al. 1986; Huang et al. 1996; Sukcharoen et al. 2014). To the best of our knowledge, no study so far has investigated the relationship between oil-price shocks and returns of oil and gas corporations during oil-price wars. Oil-price wars that take place among major oil producers cause sudden oil-price shocks which may significantly affect stock returns. Sudden drastic increases in oil supply during these wars lead to a market glut which results in falling oil prices and energy stocks.

We can identify three major oil wars during the past 25 years: The first war lasted for 17 months from November 1997 to March 1999. The feud between two Organisation of the Petroleum Exporting Countries (OPEC) members Saudi Arabia and Venezuela over violations of agreed production quota led to Saudi Arabia flooding the market, which caused prices to fall from $\$ 20$ per barrel to below $\$ 10$ within a month. Average prices plummeted to lowest levels since the 1970s.

The second war lasted for 22 months from November 2014 to August 2016. It started in November 2014 with an OPEC meeting in Vienna. Tired of non-OPEC countries freeloading on the cartel's production cuts, and worried about the impact of the United States (U.S.) shale revolution, Saudi Arabia adopted a policy of pump-at-will in spite of weak demand. Crude oil price collapsed from about $\$ 100$ per barrel to $\$ 27$ during the war period.

The latest and shortest oil war took place in March 2020 between the top OPEC exporter Saudi Arabia and the top non-OPEC exporter Russia. The war lasted only two months from March 2020 to June 2020. In response to Russia's refusal to abide by the 
OPEC decision to affect a total production cut of 3.6 million barrels per day (bpd), Saudi Arabia announced to massively increase its oil production. The brief price war added almost 100 million barrels of additional supply into an already oversupplied market, according to Bloomberg calculations. This came at a time when the world was facing an unprecedented economic slowdown resulting from the Covid-19 pandemic and the preventive lockdowns. Demand for non-essential goods and services had collapsed, industrial production had stopped, and transportation had come to a halt. As a result of the oil war, the price of oil dropped heavily. On Monday 9 March, prices fell by 30 percent, the biggest one-day drop since January 17, 1991 when oil prices fell by one-third at the outset of the 1991 Persian Gulf War.

During times of high uncertainty derived from conflict or trade wars such as the above-discussed oil wars, commodity markets such as oil experience a surge in price fluctuations (Orbaneja et al. 2018). Figures 1 and 2 show volatility clustering of the Brent and the West Texas Intermediate (WTI) crude oil prices over the 1991-2020 period. Both figures clearly indicate high volatility in crude oil prices during the three oil wars. The stocks of major oil and gas corporations also show higher volatility due to oil-supply shocks, as shown in figures A1-3 in appendix A.

Fig. 1. Examples of Volatility Clustering for Brent Oil

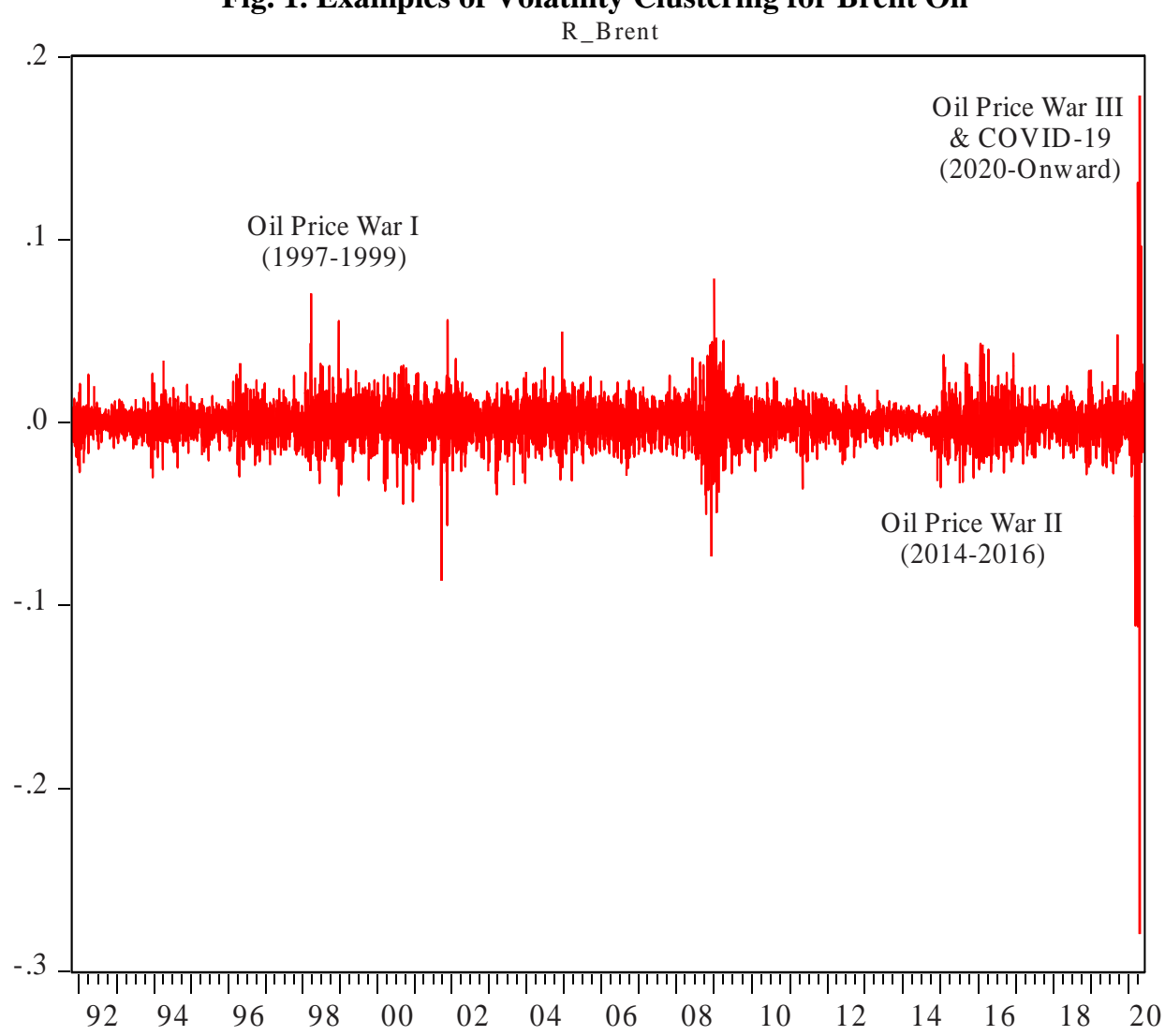

Source: Authors' calculations using U.S. Energy Information Administration (EIA) online data. 
Fig. 2. Examples of Volatility Clustering for WTI Oil

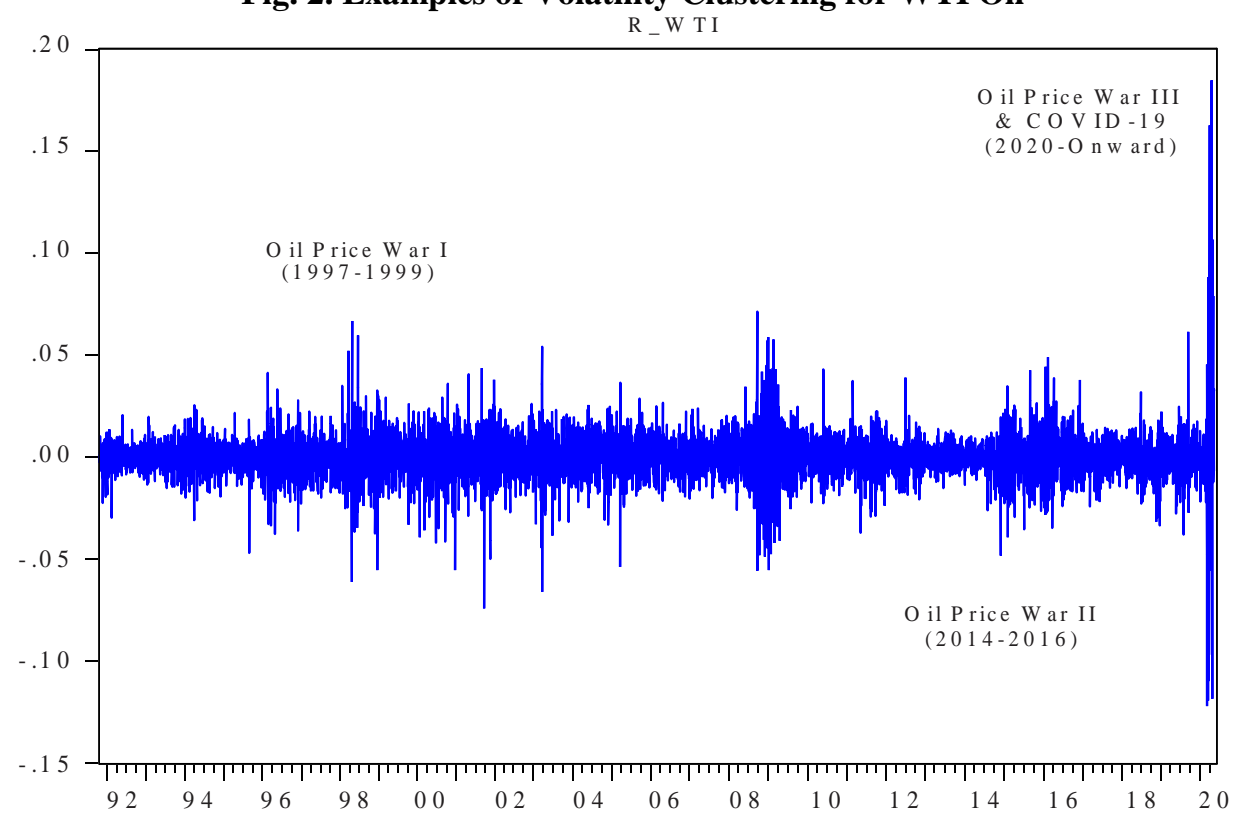

Source: Authors' calculations using U.S. Energy Information Administration (EIA) online data.

In this study, we considered 7,116 daily observations on ten largest oil and gas corporations listed on the New York Stock Exchange (NYSE) for the period from October 25, 1991 to June 8, 2020. This study is the first to consider the association between oil price shocks and returns of oil and gas corporations during the specific oilprice wars.

The contribution of our study to the extant literature is three-fold. First, this study contributes to the literature on volatility persistence in oil prices (see, Narayan and Narayan, 2007; Salisu and Fasanya, 2013; Zavadska et al., 2018). We analyse the three oil-price wars by focusing on the behaviour of the series for the whole period as well as the periods before, during and after each war episode. We rely on Generalised Autoregressive Conditional Heteroskedasticity (GARCH) and Threshold Generalised Autoregressive Conditional Heteroskedasticity (T-GARCH) models. The latter is used to test for asymmetries in the conditional variance due to deferential effect of positive and negative shocks. Furthermore, we explicitly consider structural breaks when modelling oil volatility by applying multiple break points to analyse all three oil-price war periods, as presented in Figure 1 and Figure 2. We analysed corresponding structural breaks by using the Bai and Perron structural break points test. The results of full sample period are compared with those obtained for four sub-periods: whole period, pre-war period, oil price-crisis period and post-war period. The presence of structural break points confirms abnormal behaviour in the series, which indicates higher uncertainty and elevated risk level. We find evidence for persistence and leverage effects in the oil price volatility during the three oil-price wars.

Second, the study extends recent literature on the impact of oil prices shocks on stock returns of oil and gas companies (see, Sadorsky, 2001; Lanza et al., 2005; 
Giovannini et al., 2006; Chang et al., 2009; Sanusi and Ahmad, 2016; Diaz et al., 2017; Antonakakis et al., 2018). To this end, the study brings new empirical evidence on the impact of oil price shocks arising from oil-price wars on the stock returns of oil and gas corporations using a Vector Auto-Regressive (VAR) model. We find that oil price shocks have significant and positive effect on the stock returns of oil and gas companies. Third, the study sheds light on the behaviour of the latest oil-price war in comparison with the previous episodes in the recent past. The fact that this conflict occurred at a time the world economy was collapsing due to the Covid-19 pandemic meant that both the oil and stock markets experienced some of the worst volatility ever recorded. In light of our analysis, we are able to confirm that, despite the short period, the Saudi Arabia-Russia oil-price war has higher volatility spikes than the previous two wars. We find that the impact of oil-price shocks on oil and gas stocks has been the strongest during the most recent war (March 2020).

The rest of the paper is organised as follows. Section 2 provides the review of related literature. Section 3 presents the data and methodology. Section 4 discusses the empirical results followed by concluding remarks in Section 5.

\section{RELATED LITERATURE}

Since the seminal works by Jones and Kaul (1996) and Sadorsky (1999) on the oil price-stock price nexus, various strands of literature have emerged exploring different dimensions of the relationship between oil price shocks and stock market returns. One set of studies examined oil price changes in relation to sectoral stock returns (see for instance Sadorsky, 2001; El-Sharif et al., 2005; Boyer and Filion, 2007; Nandha and Faff, 2008; Nandha and Brooks, 2009; Phan et al., 2015; Gupta, 2016; Diaz and Perez de Gracia, 2017; Tiwari et al., 2018; Kocaarslan and Soytas, 2019; Pham, 2019; Yun and Yoon, 2019). The conclusion of most of these studies is that supply-side oil price shocks have a negative effect on the stocks of industries such as transportation and aviation which have high oil input costs, while positive effects on the stock prices of oil and gas firms which are net beneficiaries of higher oil prices. Zhu et al. (2016) and Narayan and Sharma (2011) reported heterogeneous effects across firms in different industries and of different sizes.

A second set of studies focused on the type of oil price shock (supply or demand). The pioneer work of Kilian (2009) suggested that "not all oil price shocks are alike". Specifically, he proposed three types of oil price shocks: oil supply, oil demand and aggregate demand. Their study was followed by number of subsequent works including Apergis and Miller (2009), Filis et al. (2011), Broadstock and Filis (2014), Güntner (2014), Le and Chang (2015), Kang et al. (2017), Huang and Mollick (2020) and Otero (2020). These studies highlighted differential impact of demand and supply shocks in the oil market on various financial variables. For instance, Kang et al. (2017) found that oil demand-side shock has a positive effect on the return of oil and gas corporations, while Güntner (2014) noted that oil supply shocks have no significant effect on international stock markets.

A third strand of literature is based on the nature of the country as producer (oil exporting) or consumer (oil importing) (see for instance Park and Ratti, 2008; Wang et al., 2013; Bouri, 2015; Tchatoka et al., 2019; Cheema and Scrimgeour, 2019; Hamdi et 
al., 2019). Studies pertaining to oil-importing countries generally reported a negative relationship between oil price increase and stock prices (Sadorsky, 1999; Jones and Kaul, 1996; Kilian and Park, 2009; Cunado and de Gracia, 2014). Studies on oil-exporting countries, in contrast, noted an increase in stock prices as a result of increase in oil prices (Park and Ratti, 2008; Bjørnland, 2009; Gil-Alana and Yaya, 2014; Demirer et al., 2015).

As seen in this brief literature review, the body of literature on various aspects of oil price - stock linkage is substantial. However, to the best of our knowledge, no study examines the relationship by specifically focusing on the oil-price wars that take place between major oil producers. The significance of this topic lies in the fact oil-price wars are periods of sharp variations in oil prices which creates an environment of economic uncertainty. This in turn affects investors' future expectations of stock returns. The topic is of particular relevance these days as the unprecedented shock the world economy suffered as a result of the Covid-19 pandemic and the accompanying preventive lockdowns have accentuated the state of uncertainty prevailing in the commodity and stock markets.

Global oil markets have to contend, not only with the supply glut caused by the oil-price war between Saudi Arabia and Russian Federation, but also with the freeze of demand and supply chain-disruptions resulting from the coronavirus outbreak-related lockdowns. This provides an exceptional setting to study how oil-price volatility interacts with stock returns of oil and gas firms.

\section{DATA AND METHODOLOGY}

\subsection{Data}

The dataset for this study consists of 7,116 daily observations for crude oil prices and stock prices for the period from October 25, 1991 to June 8, 2020. The choice of using daily data for volatility analysis is relevant in this case as higher frequency data are required in order to accurately capture market changes (Zavadska et al., 2018). Data on Brent and West Texas Intermediate (hereafter, WTI) crude oil spot prices in the US dollars per barrel are taken from the U.S. Energy Information Administration (Thomson Reuters File). Data on stock prices come from Yahoo Finance and Datastream. ${ }^{1}$ We use the longest series available for the closing stock prices of ten largest oil and gas corporations listed on NYSE. The selected oil and gas corporations are the following: British Petroleum P.L.C. (BP), Chevron Corporation (CVX), ConocoPhillips (COP), Exxon Mobil (XOM), Hess Corporation (HES), Hollyfrontier Corporation (HFC), Royal Dutch Shell (SHELL), Suncor Energy Inc. (SU), Total SA (TOTAL), and Valero Energy Corporation (VLO). Following Bouri et al. (2016), all variables are expressed in percentages using the first differences of the natural logarithms of the price multiplied by 100 .

Table 1 identifies the summary statistics for crude oil and stocks. Following standard unit root procedures, the time series are found to be non-stationary. Consequently, first differences of logarithms are used to obtain returns. Most of the variables are negatively skewed and depicted a leptokurtic behaviour. The values for

\footnotetext{
${ }^{1}$ https://finance.yahoo.com/, http://product.datastream.com/dsws/1.0/DSLogon.aspx
} 
Table 1

Summary Statistics

\begin{tabular}{|c|c|c|c|c|c|c|c|c|c|}
\hline & Observations & Mean & Maximum & Minimum & Std. Dev. & Skewness & Kurtosis & Jarque-Bera & $\mathrm{ADF}$ \\
\hline WTI & 7,116 & 0.0171 & 42.5832 & -28.1382 & 2.6399 & 0.5904 & 30.6082 & $226,314.00(0.000)$ & $-89.85 * * *$ \\
\hline BRENT & 7,116 & 0.0189 & 41.2023 & -25.6389 & 2.4093 & 0.5593 & 28.4739 & $192,693.90(0.000)$ & $-83.73 * * *$ \\
\hline BP & 7,116 & 0.0374 & 19.5610 & -21.2006 & 1.7860 & -0.5282 & 16.9772 & $58,231.31(0.000)$ & $-82.19 * * *$ \\
\hline $\mathrm{COP}$ & 7,116 & 0.0471 & 22.4853 & -28.5552 & 1.9588 & -0.5022 & 17.7996 & $65,213.07(0.000)$ & $-88.08 * * *$ \\
\hline CVX & 7,116 & 0.0498 & 20.4904 & -25.0062 & 1.6621 & -0.4325 & 23.7158 & $127,409.90(0.000)$ & $-34.13 * * *$ \\
\hline HES & 7,116 & 0.0277 & 18.4946 & -41.0506 & 2.3746 & -1.0678 & 23.3036 & $123,527.80(0.000)$ & $-86.26 * * *$ \\
\hline HFC & 7,116 & 0.1191 & 37.0400 & -31.3984 & 2.7364 & 0.7646 & 21.0578 & $97,336.18(0.000)$ & $-84.97 * * *$ \\
\hline SHELL & 7,116 & 0.0283 & 19.4767 & -19.5932 & 1.7459 & -0.4885 & 18.5469 & $71,918.60(0.000)$ & $-81.24 * * *$ \\
\hline SU & 7,116 & 0.1141 & 358.9021 & -24.1451 & 4.8791 & 5.8478 & 90.2120 & $5,100,000.00(0.000)$ & $-80.76 * * *$ \\
\hline TOTAL & 7,116 & 0.0408 & 13.6408 & -19.6269 & 1.8099 & -0.4170 & 11.6608 & $22,436.91(0.000)$ & $-86.30 * * *$ \\
\hline VLO & 7,116 & 0.0492 & 16.5329 & -22.3144 & 2.4627 & -0.3787 & 9.9477 & $14,476.10(0.000)$ & $-44.62 * * *$ \\
\hline XOM & 7,116 & 0.0429 & 15.8631 & -15.0271 & 1.5410 & -0.0693 & 12.7112 & $27,956.07(0.000)$ & $-66.62 * * *$ \\
\hline
\end{tabular}

Notes: This table presents the summary statistics for returns of ten oil and gas corporations listed on NYSE and crude oil market (Brent and WTI Oils) based on daily data over the period of October 1991 to June 2020. Jarque and Berra (1980) is the normality statistics test for the null hypothesis of a Gaussian distribution. Furthermore, ADF is the unit root test Augmented Dickey-Fuller test (1981).***,**, * show that the null hypothesis of a unit root is rejected at $1 \%, 5 \%$ and $10 \%$ significance levels, respectively. All variables are expressed in percentages using the first differences of the natural logarithms of the price multiplied by 100. 
kurtosis show that the data are associated with simultaneously sharp peaked and fat tail. Thus, preliminary econometric analysis confirmed well-known stylised facts of crude oil and financial markets including significant autocorrelations, asymmetry, and heteroskedasticity. The high levels of kurtosis justify the use of a VAR type model as a tool to appropriately take into account non-normal co-variations between oil and stock returns of oil and gas corporations.

\subsection{Estimation Strategy}

The empirical analysis begins with a standard test for stationarity analysis, the Augmented Dickey-Fuller (ADF) test (Dickey and Fuller, 1981) and the Kwiatkowski et al. (1992) KPSS test. The null hypothesis is tested for the presence of non-stationarity (a unit root) in the variables while the alternative hypothesis is tested for stationarity of the variables. As an alternative, we use the KPSS test in place of ADF test and find similar results. $^{2}$

Next, we perform the Bai-Perron $(1998,2003)$ structural break test to examine the possibility of breaks caused by the major oil-price wars that occurred during the period under consideration. We divide each oil-price war episode into four sub-periods in order to better observe the fluctuations in oil prices that took place during the period. The first period is the whole period, the second is the pre-war period, the third is the oil pricecrisis period, and the fourth is the post-war period. The results of the structural break tests are shown in Table 2.

Table 2

\begin{tabular}{lcccc}
\multicolumn{5}{c}{ Structural Break Points-Bai-Perron Test } \\
\\
\cline { 2 - 4 } & Whole-period & Oil Price-war I & \\
\hline Break-dates & $30 / 5 / 1995$ to & $30 / 5 / 1995$ to & $1 / 12 / 1997$ to & 29/3/1999 to 5/6/2002 \\
& $5 / 6 / 2002$ & $26 / 11 / 1997$ & $25 / 3 / 1999$ & \\
& Oil Price-war II & & Post-war \\
Break-dates & Whole-period & Pre-war & Oil price crisis & Post-war \\
& $31 / 12 / 2013$ to & $31 / 12 / 2013$ to & $26 / 11 / 2014$ to & $30 / 8 / 2016$ to \\
& $18 / 9 / 2018$ & $20 / 11 / 2014$ & $29 / 8 / 2016$ & $18 / 9 / 2018$ \\
& & Oil Price-war III & & \\
Break-dates & Whole-period & Pre-war & Oil price crisis & \\
& $30 / 12 / 2019$ to & $30 / 12 / 2019$ to & $6 / 3 / 2020$ to & \\
& $5 / 6 / 2020$ & $5 / 3 / 2020$ & $21 / 4 / 2020$ & \\
\hline
\end{tabular}

Notes: This table presents the computation of structural breaks. Bai-Perron tests of L+1 vs. L sequentially are employed to identify the number and timing of breaks. The break test options include significance at 5 percent level, trimming 0.15, and maximum breaks 5. Test statistics employ HAC covariance (Prewhitening with lags from AIC, Bartlett kernel, Newey-West automatic bandwidth). The error distributions are allowed to differ across breaks.

In the next step, we model volatility in oil prices during the three oil-price wars using GARCH model presented by Bollerslev (1986) and the Threshold GARCH (TGARCH) model proposed by Zakoian (1994). Engle (1982) suggests that the variance of the residuals at the time $t$ depends on the squared error terms from past periods. The

${ }^{2}$ The results are not reported here for the sake of brevity. 
econometric specification for the mean and variance equations of $\mathrm{ARCH}$ (q) model can be given as follows:

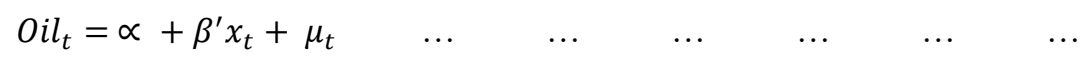

Where $\mu_{t} \mid \Omega_{t} \sim$ iid $N\left(0, \sigma^{2}{ }_{t}\right)$, and

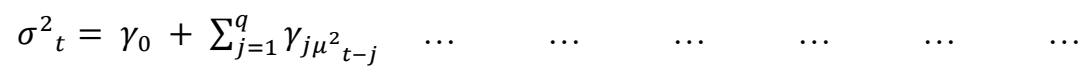

The generalised ARCH model by Bollerslev (1986) also termed as GARCH (p, q) is specified as:

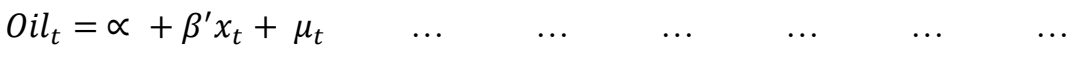

Where $\mu_{t} \mid \Omega_{t} \sim$ iid $N\left(0, \sigma^{2}{ }_{t}\right)$, and

$$
\sigma_{t}^{2}=\omega+\sum_{i=1}^{p} \alpha_{i \sigma^{2} t-i}+\sum_{j=1}^{q} \gamma_{j \mu^{2}{ }_{t-j}} \quad \ldots \quad \ldots \ldots
$$

The simplest form of GARCH (p, q) model is the GARCH (1, 1), which is extensively used in energy market research as it generally performs better than higher order GARCH models (Narayan and Narayan, 2007; Salisu and Fasanya, 2013). The variance equation for $\operatorname{GARCH}(1,1)$ is given as:

$$
\sigma_{t}^{2}=\omega+\alpha \mu_{t-1}^{2}+\beta \sigma_{t-1}^{2} \quad \ldots \quad \ldots \quad \ldots \quad \ldots \quad \ldots
$$

Equation (5) captures volatility of the previous period, measured as the lag of the squared residual term, $\left(\alpha \mu_{t-1}^{2}\right.$, the ARCH effect) and the persistence of the volatility $\left(\beta \sigma^{2}{ }_{t-1}\right.$, the GARCH effect).

The ARCH and the GARCH models are symmetric; however, it has been observed that negative shocks have larger impact on volatility than positive shocks in most financial time series such as stocks and commodities (Zavadska et al., 2018). The TGARCH model is considered more appropriate to test for asymmetries in the conditional variance and is therefore preferred in this analysis. The specification of the conditional variance equation for T-GARCH $(1,1)$ is as follows:

$$
\sigma_{t}^{2}=\omega+\alpha \mu_{t-1}^{2}+\theta \mu_{t-1}^{2} D_{t-1}+\beta \sigma_{t-1}^{2} \quad \ldots \quad \ldots \quad \ldots
$$

Where $D_{t}$ takes the value of 1 for $\mu_{t}<0$, and 0 otherwise, suggesting that positive and negative shocks have different impacts. $\alpha$ captures the impact of positive news, whereas $\alpha+\theta$ measures negative shocks. Simply, the significant and positive T-GARCH result indicates that bad (negative) news have greater impact on volatility than good (positive) news and vice versa.

In the final step, linkage between crude oil prices volatility and stock returns of oil and gas corporations is examined through VAR based methodology proposed by Sims (1980). Before estimating the VAR model, we perform preliminary tests for time series properties including the unit root test for stationarity and the test for co-integration. We assume that all the variables are integrated of order one, i.e. the variables contain a unit root. We test for cointegration (Johansen and Juselius, 1990) using both the trace and the maximum Eigenvalue tests. As shown in Tables 3 and 4, we failed to reject the null hypothesis of no cointegration among the variables of interest. In other words, the results 
Table 3

Johansen and Joselius Cointegration Tests: Trace Statistics (Full Sample)

\begin{tabular}{|c|c|c|c|c|c|c|c|c|c|}
\hline & \multicolumn{8}{|c|}{ WTI Crude Oil } & \\
\hline & \multicolumn{4}{|c|}{ Models with an Intercept } & & \multicolumn{4}{|c|}{ Models with an Intercept and a Linear Trend } \\
\hline & Hypothesis & Eigen value & Tr. statistics & Prob & & Hypothesis & Eigen value & Tr. statistics & Prob \\
\hline \multirow[t]{2}{*}{ BP - WTI } & $r=0$ & 0.00092 & 11.7241 & 0.475 & BP - WTI & $r=0$ & 0.0009 & 11.1620 & 0.205 \\
\hline & $r \leq 1$ & 0.00074 & 5.07014 & 0.274 & & $r \leq 1$ & 0.0006 & 4.9541 & 0.026 \\
\hline \multirow[t]{2}{*}{ COP - WTI } & $r=0$ & 0.00085 & 9.60818 & 0.671 & COP - WTI & $r=0$ & 0.00071 & 9.02239 & 0.367 \\
\hline & $\mathrm{r} \leq 1$ & 0.00049 & 3.47941 & 0.493 & & $\mathrm{r} \leq 1$ & 0.00046 & 3.47649 & 0.061 \\
\hline \multirow[t]{2}{*}{ CVX - WTI } & $\mathrm{r}=0$ & 0.00045 & 5.66441 & 0.963 & CVX - WTI & $\mathrm{r}=0$ & 0.00042 & 3.94817 & 0.905 \\
\hline & $\mathrm{r} \leq 1$ & 0.00035 & 2.47198 & 0.683 & & $r \leq 1$ & 0.00016 & 1.01115 & 0.315 \\
\hline \multirow[t]{2}{*}{ HES - WTI } & $r=0$ & 0.001254 & 11.8102 & 0.465 & HES - WTI & $r=0$ & 0.001240 & 11.57616 & 0.178 \\
\hline & $r \leq 1$ & 0.000392 & 2.77160 & 0.624 & & $r \leq 1$ & 0.00037 & 2.757633 & 0.096 \\
\hline \multirow[t]{2}{*}{ HFC - WTI } & $r=0$ & 0.000586 & 7.09217 & 0.891 & $\mathrm{HFC}-\mathrm{WTI}$ & $r=0$ & 0.000544 & 6.787624 & 0.602 \\
\hline & $\mathrm{r} \leq 1$ & 0.000417 & 2.94822 & 0.590 & & $\mathrm{r} \leq 1$ & 0.000416 & 2.940007 & 0.086 \\
\hline \multirow[t]{2}{*}{ SHELL - WTI } & $r=0$ & 0.000573 & 6.84067 & 0.907 & SHELL - WTI & $r=0$ & 0.000485 & 6.215734 & 0.67 \\
\hline & $\mathrm{r} \leq 1$ & 0.000394 & 2.78999 & 0.620 & & $\mathrm{r} \leq 1$ & 0.000394 & 2.787056 & 0.095 \\
\hline \multirow[t]{2}{*}{ SU - WTI } & $r=0$ & 0.000967 & 10.60615 & 0.580 & SU - WTI & $r=0$ & 0.000941 & 10.33117 & 0.256 \\
\hline & $r \leq 1$ & 0.000532 & 3.766233 & 0.448 & & $\mathrm{r} \leq 1$ & 0.000519 & 3.673405 & 0.055 \\
\hline \multirow[t]{2}{*}{ TOTAL - WTI } & $r=0$ & 0.000439 & 5.792709 & 0.958 & TOTAL - WTI & $r=0$ & 0.000421 & 4.718254 & 0.838 \\
\hline & $r \leq 1$ & 0.00038 & 2.68459 & 0.641 & & $\mathrm{r} \leq 1$ & 0.000246 & 1.74094 & 0.187 \\
\hline \multirow[t]{2}{*}{ VLO - WTI } & $r=0$ & 0.000435 & 4.630929 & 0.988 & VLO - WTI & $r=0$ & 0.000426 & 4.080497 & 0.896 \\
\hline & $r \leq 1$ & 0.00022 & 1.557551 & 0.863 & & $\mathrm{r} \leq 1$ & 0.000151 & 1.067893 & 0.301 \\
\hline \multirow[t]{2}{*}{ XOM - WTI } & $r=0$ & 0.000772 & 8.018681 & 0.822 & XOM - WTI & $r=0$ & 0.000696 & 7.199292 & 0.554 \\
\hline & $r \leq 1$ & 0.000361 & 2.554351 & 0.666 & & $r \leq 1$ & 0.000321 & 2.270858 & 0.131 \\
\hline
\end{tabular}

Notes: Tr. statistics $=$ trace statistic, $r=$ number of cointegrating vectors. The lag length in all the tests has been selected according to the Akaike Information Criteria (AIC). No cointegrating equation is traced for all oil and gas corporations with WTI crude oil. The results Brent crude oil are qualitatively consistent with the findings of WTI crude oil. The result for Brent crude oil is available with the authors and can be provided on request. 
Table 4

Johansen and Joselius Cointegration Tests: Max-Eigen Value Statistics (Full Sample)

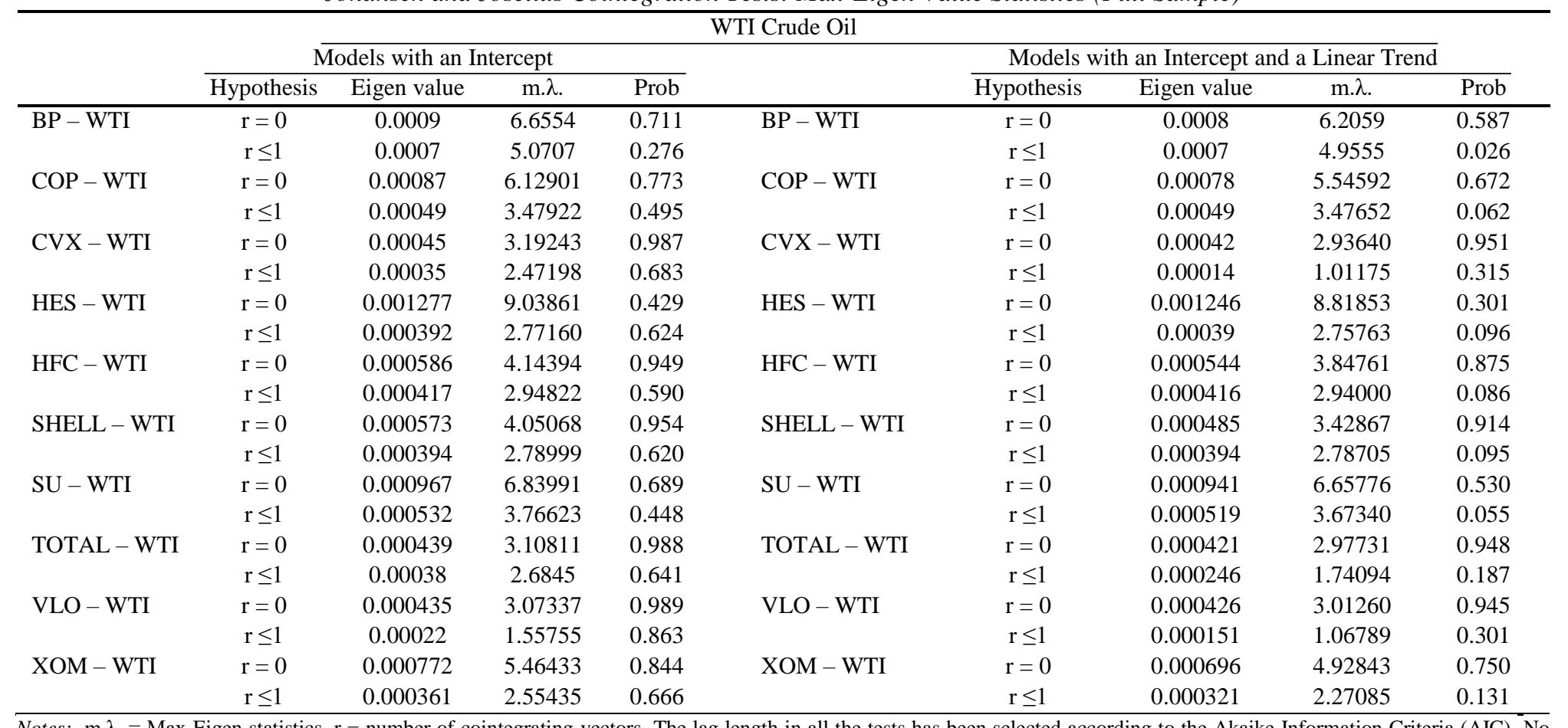

cointegrating oil. The result for Brent crude oil is available with the authors and can be provided on request. 
suggest non-existence of a long-run relationship between oil price changes and stock returns of oil and gas corporations. Consequently, we proceed to estimate VAR models for all ten oil and gas corporations.

In order to analyse the impact of oil price changes on returns of oil and gas corporations, we obtain Generalised Impulse Response Functions (GIRF) by estimating the VAR model. Moreover, unidirectional causality between oil prices changes and stock returns is captured through the Granger-causality test of the VAR system. The VAR model has been used for investigating the effect of oil price shocks on stock market returns by studies such as Park and Ratti (2008), Cunado and Perez de Gracia (2014) and Diaz and Perez de Gracia (2017). A VAR model of order $p$ that includes $k$ variables can be written as:

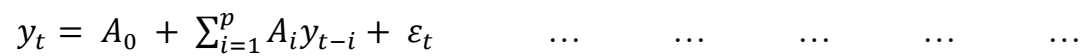

Where $p$ is the number of lags, $y_{t}=\left[\begin{array}{lll}y_{1 t} & \ldots & y_{k t}\end{array}\right]^{\prime}$ is a column vector of all the variables in the model; namely, Brent oil, WTI oil and returns of oil and gas corporations. $A_{0}$ is the constant term, $A_{i}$ is a $k \times k$ matrix of unknown coefficients, and $\varepsilon_{t}$ is the residual term with the following properties:

$$
\begin{array}{ll}
E\left(\varepsilon_{t}\right)=0 & \forall_{t}, \\
E\left(\varepsilon_{s} \varepsilon^{\prime}{ }_{t}\right)=\Omega & \text { if } s=t, \text { and } \\
E\left(\varepsilon_{s} \varepsilon^{\prime}{ }_{t}\right)=0 & \text { if } s \neq t
\end{array}
$$

$\Omega$ is the variance-covariance matrix with non-zero off-diagonal elements. The lag length is selected based on the Akaike information criterion (AIC).

\section{FINDINGS}

\subsection{Volatility Models}

We begin by discussing the volatility of oil prices and their persistence during the three oil-price wars. Table 5 presents the results of GARCH and T-GARCH models. Panels A - C show results for the first, second and third oil-price wars, respectively. With respect to the outcomes of GARCH models, oil-price wars I and II both depict positive and significant volatility levels during the four sub-periods.

For example, the price war I period shows positive and significant volatility levels during the four sub-periods for WTI oil price. Higher volatility spikes were found for the crisis and post-war periods, but persistence for long period was the main feature during the whole and pre-crisis periods. For example, the sum of ARCH and GARCH $(\alpha+\beta)$ effects in the case GARCH $(1,1)$ model for whole and pre-crisis was 0.9771 and 0.9785 respectively which is close to one. This indicates that the volatility shocks are quite persistent. Likewise, the combine effect of ARCH and GARCH for the crisis period was 0.7797 which is significantly lower than the other periods. This suggests that notable spikes are evidence of significant unsteady patterns of oil price returns particularly during the oil-price crisis period.

This finding is consistent with Figure 2 illustrate the dynamics of the WTI oil market. The behaviour of oil prices returns follows an unsteady pattern and suggests 
Table 5

Panel A: Volatility Models for the Oil Price-war I

Volatility Models

\begin{tabular}{|c|c|c|c|c|c|c|c|c|c|}
\hline & & \multicolumn{4}{|c|}{ WTI Crude Oil } & \multicolumn{4}{|c|}{ Brent Crude Oil } \\
\hline & & Whole-period & Pre-war & Oil price crisis & Post-war & Whole-period & Pre-war & Oil price crisis & Post-war \\
\hline \multirow{4}{*}{$(1,1)$} & $\omega$ & $\begin{array}{c}0.0380 * * * \\
(0.0069)\end{array}$ & $\begin{array}{c}0.0244 * * * \\
(0.0079)\end{array}$ & $\begin{array}{c}0.4296^{* * *} \\
(0.1226)\end{array}$ & $\begin{array}{c}0.2363 * * * \\
(0.0797)\end{array}$ & $\begin{array}{c}0.0340 * * * \\
(0.0081)\end{array}$ & $\begin{array}{c}0.0081 \\
(0.0051)\end{array}$ & $\begin{array}{l}0.2770^{*} \\
(0.1443)\end{array}$ & $\begin{array}{c}0.1717^{* * *} \\
(0.0670)\end{array}$ \\
\hline & $\alpha$ & $\begin{array}{c}0.0869 * * * \\
(0.0089)\end{array}$ & $\begin{array}{c}0.0965 * * * \\
(0.0186)\end{array}$ & $\begin{array}{c}0.1768^{* * * *} \\
(0.0495)\end{array}$ & $\begin{array}{c}0.1098 * * * \\
(0.0226)\end{array}$ & $\begin{array}{c}0.1042 * * * \\
(0.0080)\end{array}$ & $\begin{array}{c}0.0409 * * * \\
(0.0123)\end{array}$ & $\begin{array}{l}0.1333 * * \\
(0.0548)\end{array}$ & $\begin{array}{c}0.1181 * * * \\
(0.0221)\end{array}$ \\
\hline & $\beta$ & $0.8902 * * *$ & $0.8820^{* * *}$ & $0.6029^{* * *}$ & $0.7270 * * *$ & $0.8750 * * *$ & $0.9479 * * *$ & $0.7037 * * *$ & $0.7649 * * *$ \\
\hline & & $(0.0105)$ & $(0.0177)$ & $(0.0924)$ & $(0.0629)$ & $(0.0116)$ & $(0.0162)$ & & $(0.0613)$ \\
\hline \multirow{5}{*}{$(1,1)$} & $\omega$ & $\begin{array}{c}0.0364 * * * \\
(0.0066)\end{array}$ & $\begin{array}{c}0.0200 * * * \\
(0.0053)\end{array}$ & $\begin{array}{c}0.0595 * * * \\
(0.0234)\end{array}$ & $\begin{array}{c}0.6209 * * * \\
(0.2066)\end{array}$ & $\begin{array}{c}0.0391 * * * \\
(0.0085)\end{array}$ & $\begin{array}{c}0.0051 \\
(0.0032)\end{array}$ & $\begin{array}{c}0.2620 \\
(0.1573)\end{array}$ & $0.2440 * * *$ \\
\hline & & $0.0975^{* * * *}$ & $0.1349 * * *$ & -0.0176 & 0.0383 & $0.0813 * * *$ & $0.0558^{* * * *}$ & $0.1236^{*}$ & -0.0034 \\
\hline & $\alpha$ & $(0.0134)$ & $(0.0220)$ & $(0.0129)$ & $(0.0427)$ & $(0.0127)$ & $(0.0161)$ & $(0.0646)$ & $(0.0293)$ \\
\hline & $\theta$ & $\begin{array}{l}-0.0188 \\
(0.0151)\end{array}$ & $\begin{array}{c}0.1559 * * * \\
(0.0217)\end{array}$ & $\begin{array}{c}0.1246 * * * \\
(0.0311)\end{array}$ & $\begin{array}{c}0.1801 * * * \\
(0.0568)\end{array}$ & $\begin{array}{c}0.0448 * * * \\
(0.0139)\end{array}$ & $\begin{array}{c}0.0481 * * \\
(0.0186)\end{array}$ & $\begin{array}{c}0.0116 \\
(0.0724)\end{array}$ & $\begin{array}{c}0.2337 * * * * \\
(0.0492)\end{array}$ \\
\hline & $\beta$ & $0.8909 * * *$ & $0.9276 * * *$ & $0.9288^{* * * *}$ & $0.4280^{* * * *}$ & $0.8706 * * *$ & $0.9619 * * *$ & $0.7170^{* * * *}$ & $0.7132 * * *$ \\
\hline \multirow{2}{*}{\multicolumn{10}{|c|}{ Panel B: Volatility Models for the Oil Price-war II }} \\
\hline & & & & & & & & & \\
\hline & & \multicolumn{4}{|c|}{$\begin{array}{ll}\text { WTI Crude Oil } \\
\end{array}$} & \multicolumn{4}{|c|}{ Brent Crude Oil } \\
\hline & & Whole-period & Pre-war & Oil price crisis & Post-war & Whole-period & Pre-war & Oil price crisis & Post-war \\
\hline \multirow{6}{*}{$\begin{array}{l}\text { GARCH } \\
(1,1)\end{array}$} & & $0.0061^{* * *}$ & 0.0039 & $0.1012^{*}$ & $0.0145^{* * *}$ & $0.0018^{* *}$ & 0.0023 & 0.0964* & $0.0265^{* * *}$ \\
\hline & $\omega$ & $(0.0017)$ & $(0.0036)$ & $(0.0534)$ & $(0.0061)$ & $(0.0008)$ & $(0.0096)$ & $(0.0536)$ & $(0.0121)$ \\
\hline & $\alpha$ & $0.0532 * * *$ & 0.0345 & $0.1066 * * *$ & $0.0220^{* *}$ & $0.0427 * * *$ & 0.0323 & $0.0381 *$ & $0.0440 * * *$ \\
\hline & $\alpha$ & $(0.0086)$ & $(0.0219)$ & $(0.0394)$ & $(0.0088)$ & $(0.0071)$ & $(0.0310)$ & $(0.0200)$ & $(0.0132)$ \\
\hline & & $0.9423 * * *$ & $0.9580 * * *$ & $0.8353 * * *$ & $0.9502 * * *$ & $0.9572 * * *$ & $0.9581 * * *$ & $0.8937 * * *$ & $0.9079 * * *$ \\
\hline & $\beta$ & $(0.0082)$ & $(0.0297)$ & $(0.0576)$ & $(0.0148)$ & $(0.0069)$ & $(0.0865)$ & $(0.0517)$ & $(0.0270)$ \\
\hline \multirow{8}{*}{$\begin{array}{l}\text { T-GARCH } \\
(1,1)\end{array}$} & & $0.0049^{* * *}$ & $0.6272^{* * *}$ & 0.0072 & $0.0146 * *$ & 0.0006 & 0.0010 & -0.0056 & $0.1487^{* *}$ \\
\hline & $\omega$ & $(0.0012)$ & $(0.0479)$ & $(0.0131)$ & $(0.0063)$ & (0.0005) & $(0.0017)$ & $(0.0038)$ & $(0.0605)$ \\
\hline & & 0.0090 & $-0.0845^{* * *}$ & -0.0200 & $0.0214 * *$ & -0.0070 & $-0.0386 * *$ & $-0.0301 * * *$ & 0.0255 \\
\hline & $\alpha$ & $(0.0058)$ & $(0.0325)$ & $(0.0142)$ & (0.0104) & $(0.0047)$ & $(0.0162)$ & $(0.0072)$ & $(0.0232)$ \\
\hline & $\theta$ & $0.0570^{* * *}$ & $0.0783^{* *}$ & $0.1224 * * *$ & 0.0028 & $0.0586^{* * *}$ & $0.0393^{* * *}$ & $0.0882^{* * * *}$ & $0.1521^{* *}$ \\
\hline & $\theta$ & $(0.0116)$ & $(0.0325)$ & $(0.0320)$ & $(0.0201)$ & $(0.0081)$ & $(0.0130)$ & $(0.0193)$ & $(0.0642)$ \\
\hline & $\beta$ & $0.9575^{* * * *}$ & $-0.9535^{* * * *}$ & $0.9625^{* * * *}$ & $0.9491 * * *$ & $0.9791^{* * * *}$ & $1.0168^{* * * *}$ & $0.9977^{\text {**** }}$ & $0.6465^{* * * *}$ \\
\hline & $\beta$ & $(0.0069)$ & $(0.0354)$ & $(0.0231)$ & $(0.0162)$ & $(0.0047)$ & $(0.0190)$ & $(0.0079)$ & $(0.1141)$ \\
\hline
\end{tabular}


Table 5-(Continued)

Panel C: Volatility Models for the Oil Price-war III

\begin{tabular}{|c|c|c|c|c|c|c|c|}
\hline \multirow{4}{*}{$\begin{array}{l}\text { GARCH } \\
(1,1)\end{array}$} & \multirow{4}{*}{$\omega$} & \multicolumn{3}{|c|}{ WTI Crude Oil } & \multicolumn{3}{|c|}{ Brent Crude Oil } \\
\hline & & Whole-period & Pre-war & Oil price crisis & Whole-period & Pre-war & Oil price crisis \\
\hline & & $-0.1572 * * *$ & $0.0802 * * *$ & 0.8624 & $-0.0984 * *$ & $1.4975^{*}$ & 2.5741 \\
\hline & & $(0.0410)$ & $(0.0167)$ & $(1.0959)$ & $(0.0454)$ & $(0.8407)$ & (5.5322) \\
\hline \multirow{6}{*}{$\begin{array}{l}\text { T-GARCH } \\
(1,1)\end{array}$} & $\alpha$ & $\begin{array}{c}-0.0642 * * \\
(0.0255)\end{array}$ & $\begin{array}{c}-0.3250 * * * \\
(0.1021)\end{array}$ & $\begin{array}{c}-0.2995 * * \\
(0.1420)\end{array}$ & $\begin{array}{l}-0.06571 \\
(0.0533)\end{array}$ & $\begin{array}{l}-0.1346 \\
(0.2071)\end{array}$ & $\begin{array}{c}0.1438 \\
(0.3814)\end{array}$ \\
\hline & $\beta$ & $\begin{array}{c}0.79541 * * * \\
(0.0787)\end{array}$ & $\begin{array}{c}0.8045^{* * *} * \\
(0.1082)\end{array}$ & $\begin{array}{c}0.7801 * * * \\
(0.0581)\end{array}$ & $\begin{array}{c}0.6626 * * * \\
(0.0956)\end{array}$ & $\begin{array}{l}-0.4968 \\
(0.8759)\end{array}$ & $\begin{array}{c}0.5797 \\
(0.6851)\end{array}$ \\
\hline & $\omega$ & $0.2579^{* * *}$ & $0.1895^{* *}$ & 0.4015 & $0.0829 * *$ & 0.6078 & -0.7268 \\
\hline & $\alpha$ & $\begin{array}{c}(0.0558) \\
-0.2771 * * *\end{array}$ & $\begin{array}{c}(0.0749) \\
-0.3568 * * *\end{array}$ & $\begin{array}{c}(0.7421) \\
-0.2969^{* *}\end{array}$ & $\begin{array}{c}(0.0359) \\
-0.3056^{* * * *}\end{array}$ & $\begin{array}{l}(0.5091) \\
-0.2788\end{array}$ & $\begin{array}{c}(0.7463) \\
-0.2679\end{array}$ \\
\hline & $\theta$ & $\begin{array}{c}(0.0630) \\
1.9142 * * * \\
(0.2508)\end{array}$ & $\begin{array}{c}(0.0660) \\
0.2269 * * \\
(0.0994)\end{array}$ & $\begin{array}{c}(0.1442) \\
0.5468 * * * * \\
(0.1787)\end{array}$ & $\begin{array}{c}(0.0672) \\
0.3788^{* * * *} \\
(0.0511)\end{array}$ & $\begin{array}{c}(0.1995) \\
0.1304 \\
(0.2288)\end{array}$ & $\begin{array}{c}(0.2756) \\
2.0585 \\
(1.6230)\end{array}$ \\
\hline & $\beta$ & $\begin{array}{c}0.7427 * * * \\
(0.0497)\end{array}$ & $\begin{array}{c}0.7993^{* * * *} \\
(0.1178)\end{array}$ & $\begin{array}{c}1.1692^{\text {**** }} \\
(0.1038)\end{array}$ & $\begin{array}{c}1.1611^{\text {**** }} \\
(0.0802)\end{array}$ & $\begin{array}{c}0.5104 \\
(0.5502)\end{array}$ & $\begin{array}{c}1.1390^{* * * *} \\
(0.1173)\end{array}$ \\
\hline
\end{tabular}

Notes: ***, **, * shows statistical significance at $1 \%, 5 \%$ and $10 \%$ levels, respectively. Standard-errors are reported in parentheses. 
evidence of volatility clustering, i.e., periods of high volatility are followed by periods of relatively low volatility. The notable spikes seen in the figure are evidence of significant unsteady patterns of oil price returns particularly during the oil price crisis. These findings are consistent for WTI as well as Brent crude oil specifications.

We restrict our analysis of the third oil-price war to only the first three sub-periods (excluding the post-war period) given lack of sufficient hindsight at the time of analysis. Though the persistence of volatility is similar to that of oil-price wars I and II, oil-price war III has higher volatility spikes than the previous two wars. Since the start of the year 2020, oil prices have faced higher volatility spikes, pointing to the compounding impacts of the Covid-19 pandemic and the breakdown in the original OPEC+ agreement.

This finding of high volatility persistence in the crude oil price is consistent with the findings of Narayan and Narayan, 2007, Salisu and Fasanya (2013) and Zavadska et al. 2018) which point to variations of Brent and WTI prices.

The results for leverage effects during the three oil-price wars obtained using TGARCH models confirm the existence of asymmetries in our series for most of the same sub-periods. A significant and positive result indicates that bad (negative) news have greater impact on volatility than good (positive) news. These results are in line with findings of Wang and Wu (2012), Salisu and Fasanya (2013) and Zavadska et al. (2018). The WTI and Brent oil markets are characterised by volatility with occasional occurrence of large shocks due to geopolitical, economic or financial factors, as studied in extent literature. The GARCH $(1,1)$ model shows higher spikes and lower persistency in the Brent oil market during the most recent oil-price war. This is a direct result of the oil supply shocks of war between the two top oil producers, Saudi Arabia and Russia concomitant with the Covid-19 pandemic demand shock arising in oil importing countries, particularly China, the biggest oil importer.

\subsection{VAR Models}

Figures 3-5 show generalised impulse-response functions for response of returns on oil and gas stocks to oil price shocks during the three oil-price wars. The dotted lines show the 95 percent confidence bounds for the response of stock returns to the shocks. The shocks have the largest positive impact on stock returns during the latest oil-price war while none of the impulse response functions are significant during the second oilprice war.

Figure 3 presents the generalised impulse-response functions of oil and gas stock returns to oil price shocks during oil-price war I (1997-1999). The graph shows that volatility shock to oil prices causes a positive immediate response of the returns of oil and gas stocks. This positive impact dies out within 10 days for Shell (SHELL), Suncor Energy Inc. (SU) and Total SA (TOTAL), however, the impact persists for 3 to 5 days for other companies.

Figure 4 exhibits the generalised impulse-response functions of oil and gas stock returns to oil price shocks during oil-price war II (2014-2016). The results indicate that none of the impulse response functions are significant, suggesting that the shock to crude oil price did not affect returns on oil and gas companies in the short-run.

Finally, Figure 5 presents the generalised impulse-response functions of oil and gas stock returns to oil price shocks during oil-price war III (2020). A volatility shock to 
Fig. 3. Generalised Impulse-response Functions of Oil and Gas Stock Returns to Oil Price Shocks During Oil-price War I (1997-1999)

BP

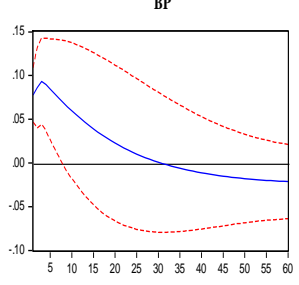

HFC

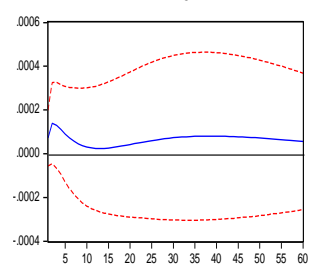

VLO

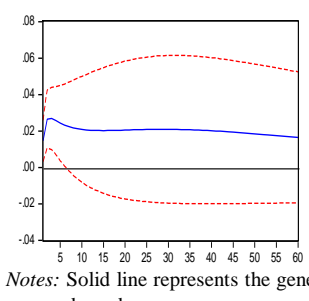
bounds.
COP

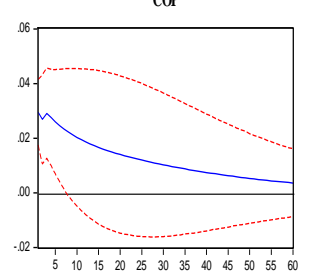

SHELL

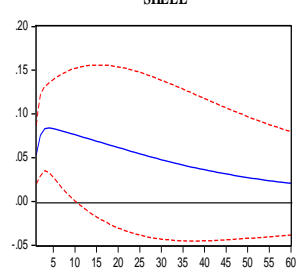

XOM

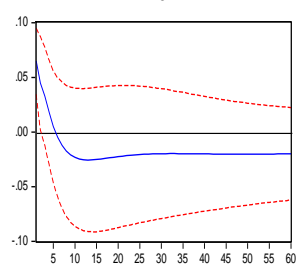

cVX

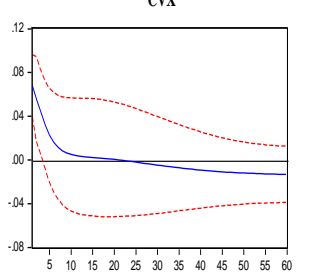

SU
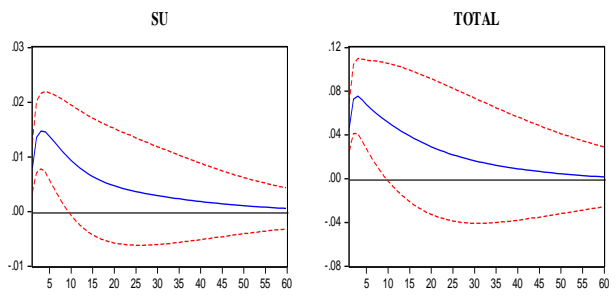

HES

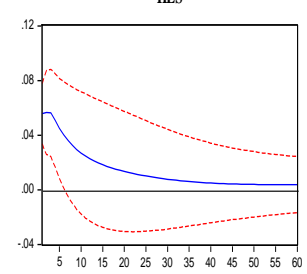

TOTAL

Accumulated Response to WTI crude oil

Fig. 4. Generalised Impulse-response Functions of Oil and Gas Stock Returns to Oil Price Shocks During Oil-price War II (2014-2016)
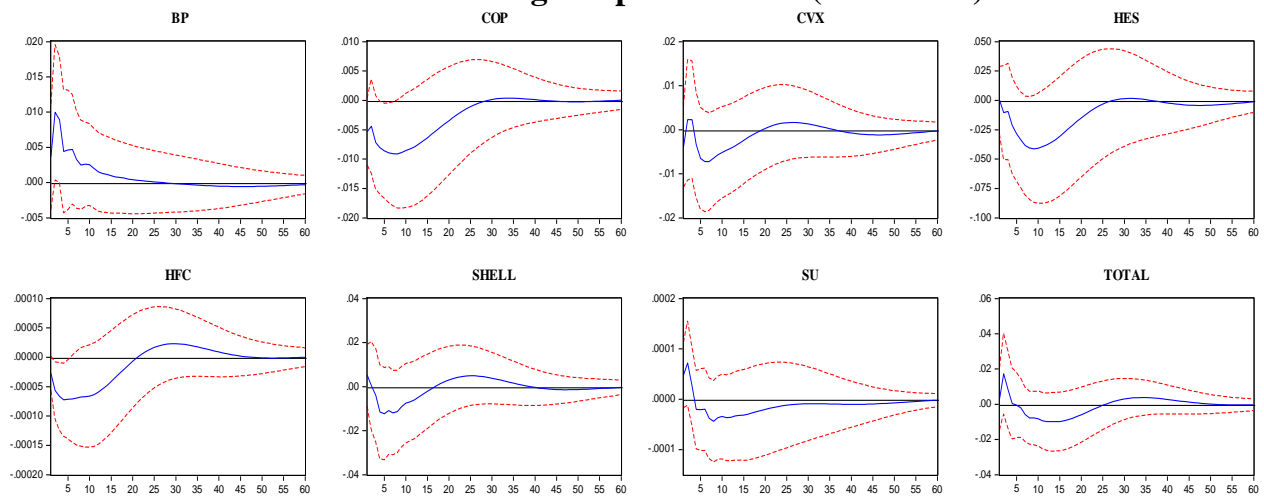

VLO
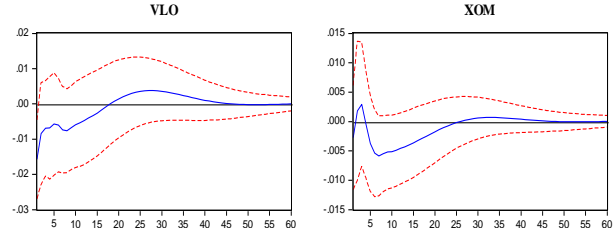

Accumulated Response to WTI crude oil

Notes: Solid line represents the generalised response function of stock returns to a shock in oil price change. Dotted lines are 95 percent confidence bounds. 
Fig. 5. Generalised Impulse-response Functions of Oil and Gas Stock Returns to Oil Price Shocks During Oil-price War III (2020-Onward)
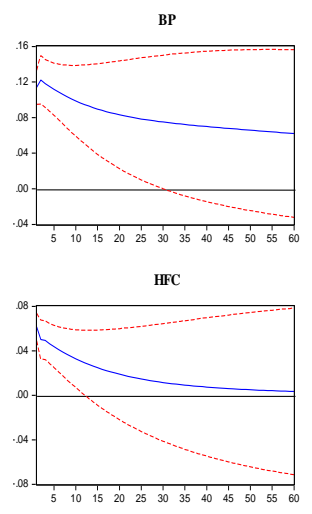

vLO
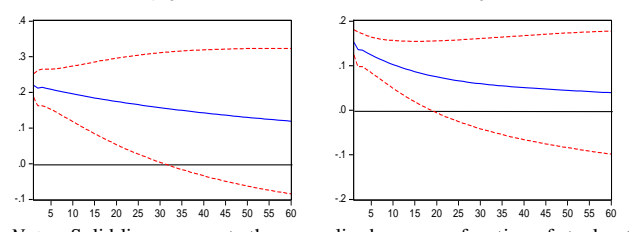

COP

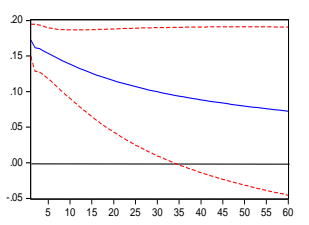

SHELL

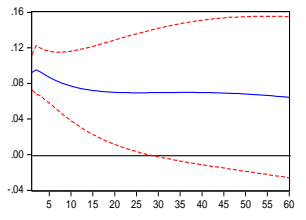

xоM

Accumulated Response to WTI crude oil

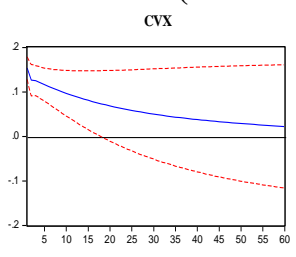

$\mathrm{su}$

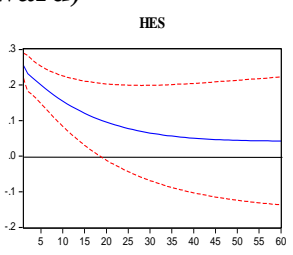

TOTAL
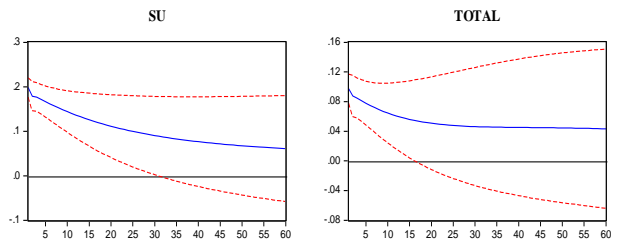

oil prices during this war causes a positive effect on the returns of oil and gas companies within the week of the shock. The impulse responses mostly last 30 to 35 days for British Petroleum P.L.C. (BP), ConocoPhillips (COP), Suncor Energy Inc. (SU), and Valero Energy Corporation (VOL). Overall, the positive impact seems to be persistent in the short term but the risk transmission is more significant in case of the third oil price war.

The impulse-response functions computed for Brent oil prices show a similar pattern of response to shocks to oil and gas stocks as those for WTI. ${ }^{3}$

Earlier studies on the impact of oil supply and demand shocks on stock market returns in the US (Kilian and Park, 2009; Apergis and Miller, 2009) and European countries (Cunado and de Gracia, 2014) reported a significantly negative effect of oil price shocks on stock market returns. However, recent studies by Gupta (2016), Diaz and Perez de Gracia (2017), Luo and Qin (2017) and Wen et al. (2019) report opposite results. In line with these recent studies, we also find a significantly positive effect of oil price shocks on oil and gas corporations listed on NYSE in the short-run. We find that stock returns of oil and gas corporations are sensitive to price shocks that arise from oilprice wars among oil producers.

Finally, we look for Granger causality between our oil-price and stock returns variables. Table 6 reports the results for Granger-causality test. We reject the null hypothesis of no Granger-causality for most of the oil and gas corporations with both WTI and Brent crude oil prices. Therefore, a unidirectional granger causality exists between crude oil and the stock returns of oil and gas corporations listed on NYSE. This is consistent with the findings of Diaz and Perez de Gracia (2017).

${ }^{3}$ The results are not reported for brevity purpose. 
Table 6

Granger Causality Test

\begin{tabular}{|c|c|c|c|c|c|c|c|c|c|c|c|}
\hline & \multicolumn{3}{|c|}{ (Oil-price war-I) } & \multicolumn{5}{|c|}{ (Oil-price war-II) } & \multicolumn{3}{|c|}{ (Oil-price war-III) } \\
\hline & $\overline{\text { WTI }}$ & & Brent & & $\overline{\text { WTI }}$ & & Brent & & WTI & & $\overline{\text { Brent }}$ \\
\hline $\mathrm{BP} \rightarrow \mathrm{WTI}$ & 0.4537 & $\mathrm{BP} \rightarrow \mathrm{Brent}$ & 1.3348 & $\mathrm{BP} \rightarrow \mathrm{WTI}$ & 1.6629 & $\mathrm{BP} \rightarrow$ Brent & 0.5559 & $\mathrm{BP} \rightarrow \mathrm{WTI}$ & 1.7220 & $\mathrm{BP} \rightarrow$ Brent & 1.7558 \\
\hline $\mathrm{WTI} \rightarrow \mathrm{BP}$ & $5.2621 * * *$ & Brent $\rightarrow$ BP & $5.7128 * * *$ & $\mathrm{WTI} \rightarrow \mathrm{BP}$ & 1.6507 & Brent $\rightarrow$ BP & $11.4788 * * *$ & $\mathrm{WTI} \rightarrow \mathrm{BP}$ & $7.2098 * * *$ & Brent $\rightarrow$ BP & 1.5601 \\
\hline $\mathrm{COP} \rightarrow \mathrm{WTI}$ & 0.0404 & $\mathrm{COP} \rightarrow \mathrm{Brent}$ & 0.0648 & $\mathrm{COP} \rightarrow \mathrm{WTI}$ & 1.1165 & $\mathrm{COP} \rightarrow$ Brent & 1.0985 & $\mathrm{COP} \rightarrow \mathrm{WTI}$ & 1.4526 & $\mathrm{COP} \rightarrow$ Brent & 1.5827 \\
\hline $\mathrm{WTI} \rightarrow \mathrm{COP}$ & $2.9271^{*}$ & Brent $\rightarrow \mathrm{COP}$ & $2.6196^{*}$ & $\mathrm{WTI} \rightarrow \mathrm{COP}$ & $4.0206^{* *}$ & Brent $\rightarrow$ COP & $14.7991 * * *$ & $\mathrm{WTI} \rightarrow \mathrm{COP}$ & $4.1240 * *$ & Brent $\rightarrow$ COP & 0.4231 \\
\hline $\mathrm{CVX} \rightarrow \mathrm{WTI}$ & 0.6169 & $\mathrm{CVX} \rightarrow$ Brent & 1.4947 & $\mathrm{CVX} \rightarrow \mathrm{WTI}$ & 0.7458 & $\mathrm{CVX} \rightarrow$ Brent & 0.6025 & $\mathrm{CVX} \rightarrow \mathrm{WTI}$ & 1.9529 & $\mathrm{CVX} \rightarrow \mathrm{Brent}$ & 1.5059 \\
\hline $\mathrm{WTI} \rightarrow \mathrm{CVX}$ & 2.1932 & Brent $\rightarrow \mathrm{CVX}$ & 0.1811 & $\mathrm{WTI} \rightarrow \mathrm{CVX}$ & $3.6250 * *$ & Brent $\rightarrow$ CVX & 0.3336 & $\mathrm{WTI} \rightarrow \mathrm{CVX}$ & $4.0709 * *$ & Brent $\rightarrow \mathrm{CVX}$ & 0.8947 \\
\hline $\mathrm{HES} \rightarrow$ WTI & 2.7913 & HES $\rightarrow$ Brent & 0.3344 & $\mathrm{HES} \rightarrow \mathrm{WTI}$ & 1.4758 & HES $\rightarrow$ Brent & 0.9128 & $\mathrm{HES} \rightarrow \mathrm{WTI}$ & 1.2996 & $\mathrm{HES} \rightarrow$ Brent & 1.1336 \\
\hline $\mathrm{WTI} \rightarrow \mathrm{HES}$ & $3.9146^{* * *}$ & Brent $\rightarrow$ HES & $5.9017 * * *$ & WTI $\rightarrow$ HES & $3.0081^{*}$ & Brent $\rightarrow$ HES & $1.8471^{* * *}$ & $\mathrm{WTI} \rightarrow \mathrm{HES}$ & $5.1981 * * *$ & Brent $\rightarrow$ HES & 0.2052 \\
\hline $\mathrm{HFC} \rightarrow$ WTI & 0.2688 & $\mathrm{HFC} \rightarrow$ Brent & 1.5348 & $\mathrm{HFC} \rightarrow \mathrm{WTI}$ & 0.2074 & $\mathrm{HFC} \rightarrow$ Brent & 1.1797 & $\mathrm{HFC} \rightarrow \mathrm{WTI}$ & 1.5205 & $\mathrm{HFC} \rightarrow$ Brent & 0.7864 \\
\hline $\mathrm{WTI} \rightarrow \mathrm{HFC}$ & 1.7982 & Brent $\rightarrow$ HFC & 0.2533 & $\mathrm{WTI} \rightarrow \mathrm{HFC}$ & $2.8863^{*}$ & Brent $\rightarrow$ HFC & $4.3770 * *$ & $\mathrm{WTI} \rightarrow \mathrm{HFC}$ & $2.8248^{*}$ & Brent $\rightarrow$ HFC & 1.6412 \\
\hline $\mathrm{SHELL} \rightarrow \mathrm{WTI}$ & 2.0259 & SHELL $\rightarrow$ Brent & 4.5034 & SHELL $\rightarrow$ WTI & 2.0518 & SHELL $\rightarrow$ Brent & 0.0087 & $\mathrm{SHELL} \rightarrow \mathrm{WTI}$ & 2.0690 & SHELL $\rightarrow$ Brent & $2.9656^{*}$ \\
\hline WTI $\rightarrow$ SHELL & $5.9021 * * *$ & Brent $\rightarrow$ SHELL & $3.0937^{* *}$ & WTI $\rightarrow$ SHELL & 0.4942 & Brent $\rightarrow$ SHELL & $12.4930 * * *$ & WTI $\rightarrow$ SHELL & $8.2302 * * *$ & Brent $\rightarrow$ SHELL & 2.3596 \\
\hline $\mathrm{SU} \rightarrow \mathrm{WTI}$ & 0.1211 & $\mathrm{SU} \rightarrow$ Brent & 0.9857 & $\mathrm{SU} \rightarrow \mathrm{WTI}$ & 1.8273 & $\mathrm{SU} \rightarrow$ Brent & 0.2614 & $\mathrm{SU} \rightarrow \mathrm{WTI}$ & 0.7438 & $\mathrm{SU} \rightarrow$ Brent & 1.2084 \\
\hline $\mathrm{WTI} \rightarrow \mathrm{SU}$ & $5.3780^{* * *}$ & Brent $\rightarrow \mathrm{SU}$ & 1.3136 & $\mathrm{WTI} \rightarrow \mathrm{SU}$ & $3.0703 * *$ & Brent $\rightarrow$ SU & $12.6091 * * *$ & $\mathrm{WTI} \rightarrow \mathrm{SU}$ & $2.6752 *$ & Brent $\rightarrow$ SU & 1.0430 \\
\hline TOTAL $\rightarrow$ WTI & 1.9758 & TOTAL $\rightarrow$ Brent & 4.7679 & TOTAL $\rightarrow$ WTI & 2.0782 & TOTAL $\rightarrow$ Brent & 0.2036 & TOTAL $\rightarrow$ WTI & 1.3760 & TOTAL $\rightarrow$ Brent & 0.3935 \\
\hline $\mathrm{WTI} \rightarrow \mathrm{TOTAL}$ & $8.1919^{* * *}$ & Brent $\rightarrow$ TOTAL & $3.4981^{* *}$ & $\mathrm{WTI} \rightarrow \mathrm{TOTAL}$ & 1.0236 & Brent $\rightarrow$ TOTAL & $8.5198^{* * *}$ & $\mathrm{WTI} \rightarrow \mathrm{TOTAL}$ & 1.1493 & Brent $\rightarrow$ TOTAL & $1.2131^{* *}$ \\
\hline $\mathrm{VLO} \rightarrow$ WTI & 3.3014 & $\mathrm{VLO} \rightarrow$ Brent & 0.9423 & $\mathrm{VLO} \rightarrow$ WTI & 0.1599 & $\mathrm{VLO} \rightarrow$ Brent & 0.4286 & $\mathrm{VLO} \rightarrow$ WTI & 0.7545 & $\mathrm{VLO} \rightarrow$ Brent & 0.7427 \\
\hline $\mathrm{WTI} \rightarrow \mathrm{VLO}$ & $5.9948 * * *$ & Brent $\rightarrow$ VLO & 0.6530 & $\mathrm{WTI} \rightarrow \mathrm{VLO}$ & $4.6952 * * *$ & Brent $\rightarrow$ VLO & $6.3424 * * *$ & $\mathrm{WTI} \rightarrow \mathrm{VLO}$ & $4.1347 * *$ & Brent $\rightarrow$ VLO & $3.1160^{* *}$ \\
\hline $\mathrm{XOM} \rightarrow$ WTI & 0.8223 & $\mathrm{XOM} \rightarrow$ Brent & 1.3436 & $\mathrm{XOM} \rightarrow \mathrm{WTI}$ & 0.9927 & $\mathrm{XOM} \rightarrow$ Brent & 0.5965 & $\mathrm{XOM} \rightarrow$ WTI & 2.1642 & $\mathrm{XOM} \rightarrow$ Brent & 1.4334 \\
\hline $\mathrm{WTI} \rightarrow \mathrm{XOM}$ & $2.6140^{*}$ & Brent $\rightarrow$ XOM & $0.8290 * *$ & $\mathrm{WTI} \rightarrow \mathrm{XOM}$ & 0.1007 & Brent $\rightarrow \mathrm{XOM}$ & $1.6561 * * *$ & $\mathrm{WTI} \rightarrow \mathrm{XOM}$ & $6.4695^{* * *}$ & Brent $\rightarrow \mathrm{XOM}$ & $0.7695^{* *}$ \\
\hline
\end{tabular}

Note: $* * *$, and $* * *$ denotes rejection of null hypothesis the at $1 \%, 5 \%$ and $10 \%$ significance level. 


\section{CONCLUSIONS AND POLICY IMPLICATIONS}

The uncertainties involved in high spikes of oil prices and related volatility arising due to supply or demand disruptions influence the decision-making process of investors, speculators and policy makers. In this study, we examined the effects of crude oil price supply-shocks on the returns to stocks of ten largest oil and gas corporations listed on NYSE during three oil-price wars that took place among major oil producers during the past thirty years. Our sample comprised of daily observations for crude oil prices and stock prices for the period from October 25, 1991 to June 8, 2020 with a total of 7,116 observations. We computed the persistence of volatility in oil prices during times of specific oil-price wars through GARCH (Generalised Autoregressive Conditional Heteroskedasticity) model and tested for the presence of leverage effects using T-GARCH (Threshold Generalised Autoregressive Conditional Heteroskedasticity) model. The period of estimation was divided into four sub-periods for each oil-price war: the whole period. pre-war period, oil price-crisis period, and post-war period. We tested for structural breaks that might occur due to the irregular nature of oil-price wars by using the Bai and Perron $(1998,2003)$ model. Furthermore, we investigated the linkage between oil price shocks and stock returns using a VAR (vector autoregressive) model.

Our results provide evidence for persistence in oil price volatility as well as for leverage effects during three oil-price wars. The persistence is the highest in case of the latest war, highlighting the twin impact of supply shock and demand shocks that have arisen due to the co-occurrence of the oil-price war and the global economic slowdown caused by the Covid-19 pandemic. We also found that oil-price shocks have significant and positive effect on the returns of major oil and gas companies. The impact has been the most potent during the 2020 oil-price war.

The positive impact of the oil-price shock on returns on stocks of oil and gas firms listed on the NYSE is in line with previous findings in the literature (see, for example, Gupta, 2016; Diaz and Perez de Gracia, 2017; Kang et al., 2017; Huang and Mollick, 2020). This supports the view that on average, the world economy benefits from higher oil prices. This was not the case when the U.S. was a net petroleum importer. Foroni et al. (2017) show that the sign of the relation between oil prices and the U.S. stock returns had changed over time, having turned positive since early 2007.

These findings provide an important insight that oil price volatility driven by wars among oil exporters has significant impact on stock returns. These findings provide investors information on how volatility in global oil prices is also sensitive to irregular events such as price wars between oil producers. This information can be important for economic agents contemplating shorter hedges by managing risks during times of high volatility.

This work can be extended by employing data mining and machine learning techniques using extensive datasets, especially for the third war period, given that data from this latest war period are still in infancy. 


\section{Appendix-A}

Fig. A1. This Figure Shows the Volatility Clustering for Crude Oils and Oil and Gas Corporations During Oil-price War I (November 1997 to March 1999)
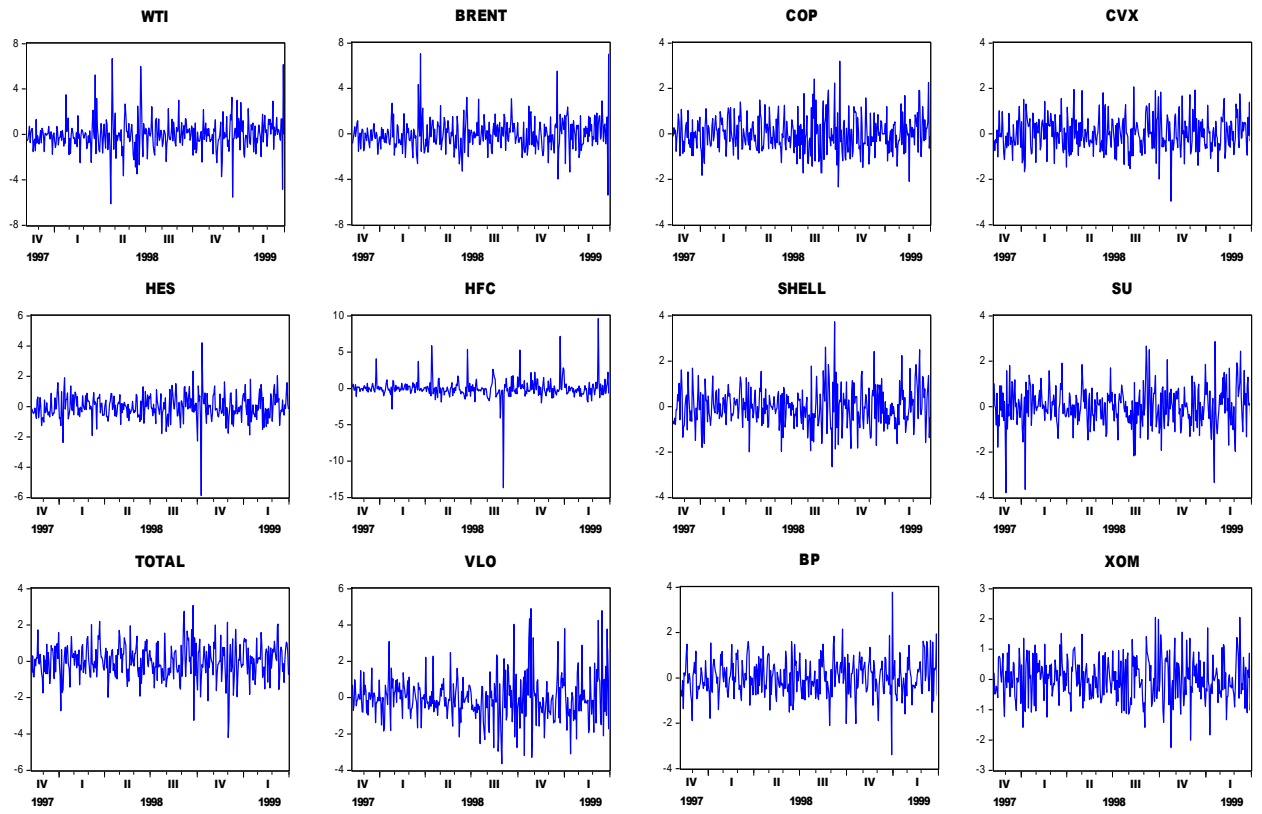

Fig. A2. This Figure Exhibits the Volatility Clustering for Crude Oils and Oil and Gas Corporations During Oil-price War II (November 2014 to August 2016)
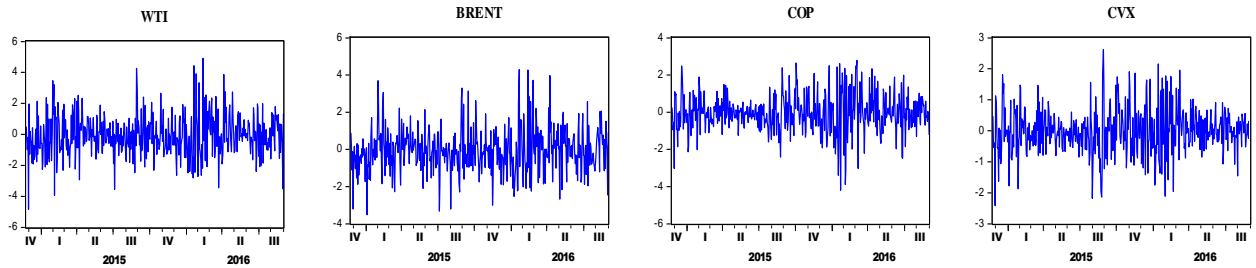

HES

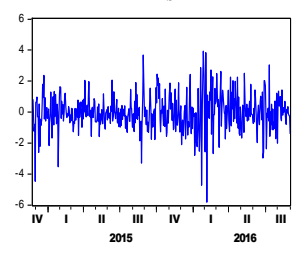

$\mathrm{HFC}$

SHELL
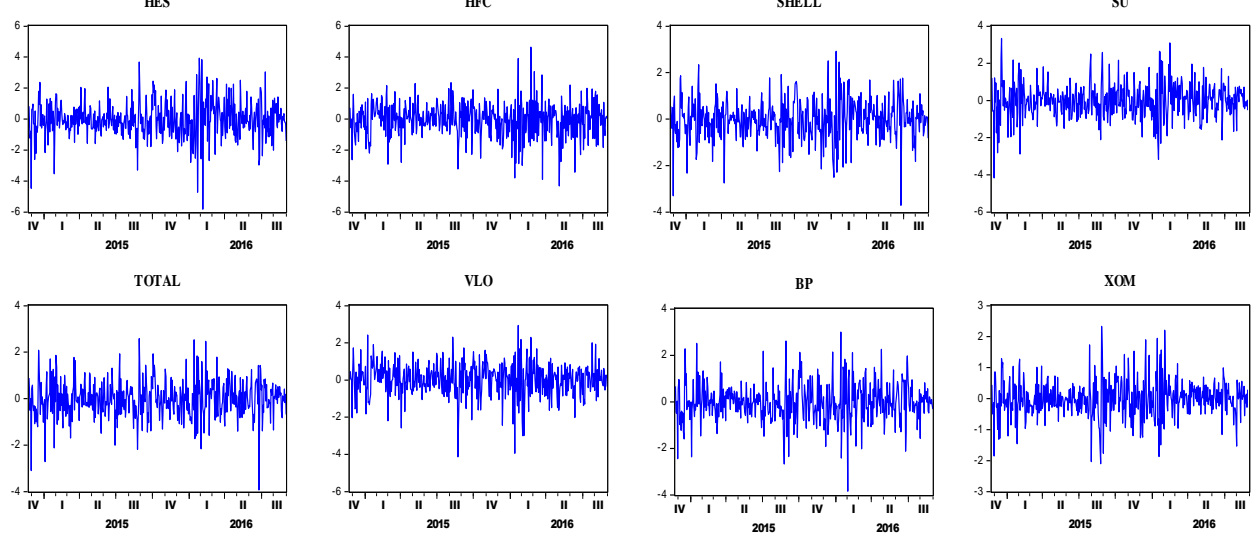
Fig. A3. This Figure Presents the Volatility Clustering for Crude Oils and Oil and Gas Corporations During Oil-price War III (9 March 2020 and onwards)
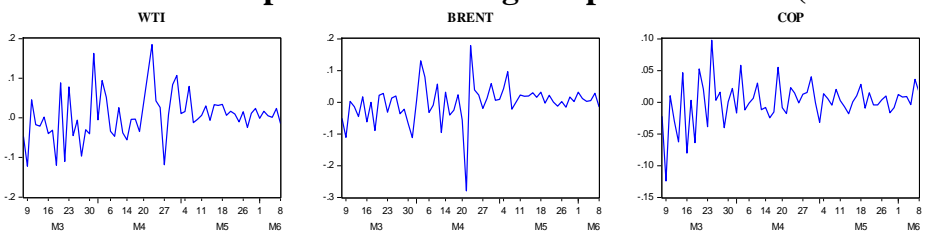

crx

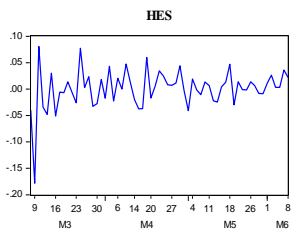

$\mathrm{HFC}$

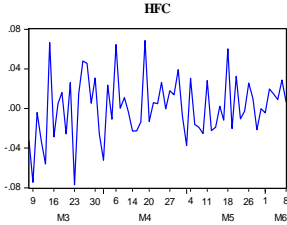

SHELL
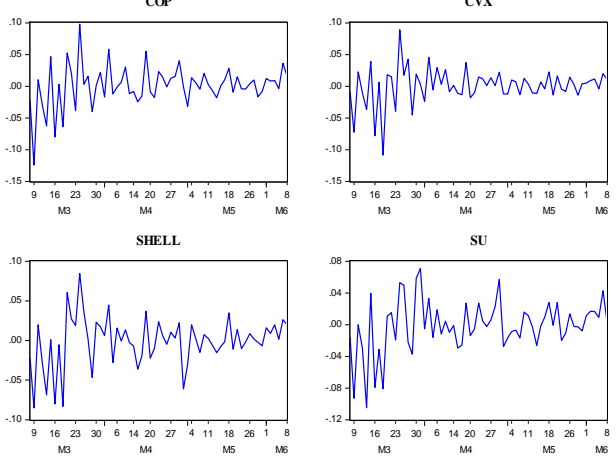

Toт

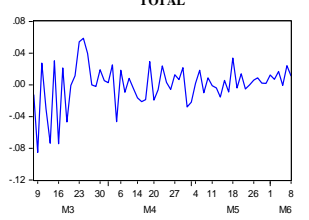

vLO

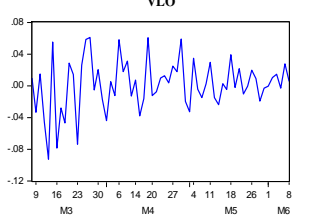

BP
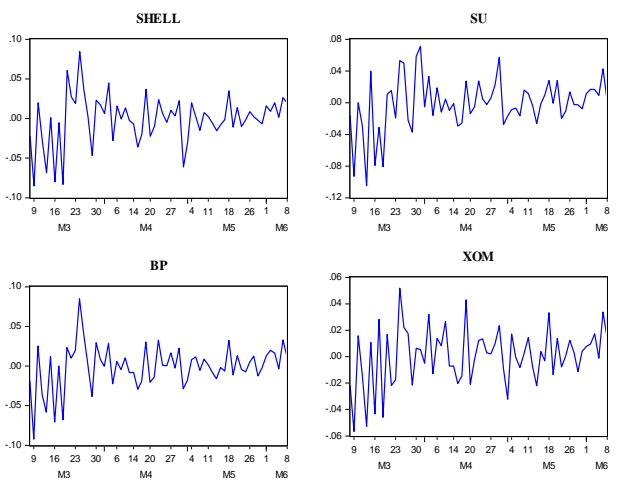

XOM

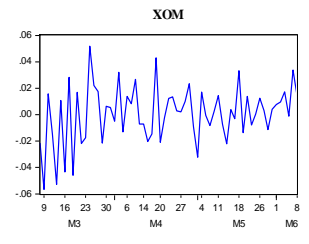

\section{REFERENCES}

Antonakakis, N., Cunado, J., Filis, G., Gabauer, D., \& De Gracia, F. P. (2018). Oil volatility, oil and gas firms and portfolio diversification. Energy Economics, 70, 499515.

Apergis, N., \& Miller, S. M. (2009). Do structural oil-market shocks affect stock prices? Energy Economics, 31(4), 569-575.

Bai, J., \& Perron, P. (1998). Estimating and testing linear models with multiple structural changes. Econometrica, 47-78.

Bai, J., \& Perron, P. (2003). Computation and analysis of multiple structural change models. Journal of applied econometrics, 18(1), 1-22.

Bloomberg (2020). 'When will the oil war end? History signals a long wait'. URL: https://www.bloomberg.com/news/articles/2020-03-18/when-will-the-oil-war-endhistory-signals-a-long-wait

Bollerslev, T. (1986). Generalised autoregressive conditional heteroskedasticity. Journal of Econometrics, 31(3), 307-327.

Bouri, E. (2015). Oil volatility shocks and the stock markets of oil-importing MENA economies: A tale from the financial crisis. Energy Economics, 51, 590-598.

Bouri, E., Awartani, B., \& Maghyereh, A. (2016). Crude oil prices and sectoral stock returns in Jordan around the Arab uprisings of 2010. Energy Economics, 56, 205-214.

Boyer, M. M., \& Filion, D. (2007). Common and fundamental factors in stock returns of Canadian oil and gas companies. Energy Economics, 29(3), 428-453.

Chang, C. L., McAleer, M., Tansuchat, R. (2009). Volatility spillovers between returns on crude oil futures and oil company stocks. Available at SSRN: http: //ssrn.com/abstract=1406983.

Cheema, M. A., \& Scrimgeour, F. (2019). Oil prices and stock market anomalies. Energy Economics, 83, 578-587. 
Chen, N. F., Roll, R., \& Ross, S. A. (1986). Economic forces and the stock market. Journal of Business, 383-403.

Cunado, J., \& de Gracia, F. P. (2014). Oil price shocks and stock market returns: Evidence for some European countries. Energy Economics, 42, 365-377.

Diaz, E. M., \& de Gracia, F. P. (2017). Oil price shocks and stock returns of oil and gas corporations. Finance Research Letters, 20, 75-80.

Diaz, E. M., Molero, J. C., \& de Gracia, F. P. (2016). Oil price volatility and stock returns in the G7 economies. Energy Economics, 54, 417-430.

Dickey, D. A., \& Fuller, W. A. (1981). Likelihood ratio statistics for autoregressive time series with a unit root. Econometrica: Journal of the Econometric Society, 1057-1072.

Driesprong, G., Jacobsen, B., \& Maat, B. (2008). Striking oil: Another puzzle? Journal of Financial Economics, 89(2), 307-327.

El-Sharif, I., Brown, D., Burton, B., Nixon, B., \& Russell, A. (2005). Evidence on the nature and extent of the relationship between oil prices and equity values in the UK. Energy Economics, 27(6), 819-830.

Engle, R. F. (1982). Autoregressive conditional heteroscedasticity with estimates of the variance of United Kingdom inflation. Econometrica: Journal of the Econometric Society, 987-1007.

Foroni, C., Guérin, P., \& Marcellino, M. (2017). Explaining the time-varying effects of oil market shocks on US stock returns. Economics Letters, 155, 84-88.

Giovannini, M., Grasso, M., Lanza, A., \& Manera, M. (2006). Conditional correlations in the returns on oil companies stock prices and their determinants. Empirica, 33(4), 193-207.

Gupta, K. (2016). Oil price shocks, competition, and oil \& gas stock returns-Global evidence. Energy Economics, 57, 140-153.

Hamdi, B., Aloui, M., Alqahtani, F., \& Tiwari, A. (2019). Relationship between the oil price volatility and sectoral stock markets in oil-exporting economies: Evidence from wavelet nonlinear denoised based quantile and Granger-causality analysis. Energy Economics, 80, 536-552.

Huang, R. D., Masulis, R. W., \& Stoll, H. R. (1996). Energy shocks and financial markets. Journal of Futures Markets, 16(1), 1-27.

Huang, W., \& Mollick, A. V. (2020). Tight oil, real WTI prices and US stock returns. Energy Economics, 85, 104574.

Jones, C. M., \& Kaul, G. (1996). Oil and the stock markets. The Journal of Finance, 51(2), 463-491.

Joo, Y. C., \& Park, S. Y. (2017). Oil prices and stock markets: Does the effect of uncertainty change over time? Energy Economics, 61, 42-51.

Kang, W., de Gracia, F. P., \& Ratti, R. A. (2017). Oil price shocks, policy uncertainty, and stock returns of oil and gas corporations. Journal of International Money and Finance, 70, 344-359.

Kilian, L. (2008). Exogenous oil supply shocks: how big are they and how much do they matter for the US economy? The Review of Economics and Statistics, 90(2), 216-240.

Kilian, L. (2009). Not all oil price shocks are alike: Disentangling demand and supply shocks in the crude oil market. American Economic Review, 99(3), 1053-69. 
Kilian, L., \& Park, C. (2009). The impact of oil price shocks on the US stock market. International Economic Review, 50(4), 1267-1287.

Kocaarslan, B., \& Soytas, U. (2019). Dynamic correlations between oil prices and the stock prices of clean energy and technology firms: The role of reserve currency (US dollar). Energy Economics, 104502.

Kwiatkowski, D., Phillips, P.C.B., Schmidt, P. and Shin, Y. (1992). Testing the null hypothesis of stationarity against the alternative of a unit root: how sure are we that economic time series have a unit root? Journal of Econometrics, 54, 159-178.

Lanza, A., Manera, M., Grasso, M., \& Giovannini, M. (2005). Long-run models of oil stock prices. Environmental Modelling \& Software, 20(11), 1423-1430.

Luo, X., \& Qin, S. (2017). Oil price uncertainty and Chinese stock returns: New evidence from the oil volatility index. Finance Research Letters, 20, 29-34.

Mensi, W., Hammoudeh, S., Shahzad, S. J. H., \& Shahbaz, M. (2017). Modeling systemic risk and dependence structure between oil and stock markets using a variational mode decomposition-based copula method. Journal of Banking \& Finance, 75, 258-279.

Nandha, M., \& Brooks, R. (2009). Oil prices and transport sector returns: an international analysis. Review of Quantitative Finance and Accounting, 33(4), 393-409.

Nandha, M., \& Faff, R. (2008). Does oil move equity prices? A global view. Energy Economics, 30(3), 986-997.

Narayan, P. K., \& Narayan, S. (2007). Modelling oil price volatility. Energy Policy, 35(12), 6549-6553.

Narayan, P. K., \& Narayan, S. (2010). Modelling the impact of oil prices on Vietnam's stock prices. Applied Energy, 87(1), 356-361.

Orbaneja, J. R. V., Iyer, S. R., \& Simkins, B. J. (2018). Terrorism and oil markets: A cross-sectional evaluation. Finance Research Letters, 24, 42-48.

Otero, J. D. Q. (2020). Not all sectors are alike: Differential impacts of shocks in oil prices on the sectors of the Colombian economy. Energy Economics, 86, 104691.

Park, J., \& Ratti, R. A. (2008). Oil price shocks and stock markets in the US and 13 European countries. Energy Economics, 30(5), 2587-2608.

Pham, L. (2019). Do all clean energy stocks respond homogeneously to oil price?. Energy Economics, 81, 355-379.

Sadorsky, P. (1999). Oil price shocks and stock market activity. Energy Economics, 21(5), 449-469.

Sadorsky, P. (2001). Risk factors in stock returns of Canadian oil and gas companies. Energy Economics, 23(1), 17-28.

Salisu, A. A., \& Fasanya, I. O. (2013). Modelling oil price volatility with structural breaks. Energy Policy, 52, 554-562.

Sanusi, M. S., \& Ahmad, F. (2016). Modelling oil and gas stock returns using multi factor asset pricing model including oil price exposure. Finance Research Letters, 18, 89-99.

Sims, C. A. (1980). Macroeconomics and reality. Econometrica: journal of the Econometric Society, 1-48.

Sukcharoen, K., Zohrabyan, T., Leatham, D., \& Wu, X. (2014). Interdependence of oil prices and stock market indices: A copula approach. Energy Economics, 44, 331-339. 
Tchatoka, F. D., Masson, V., \& Parry, S. (2019). Linkages between oil price shocks and stock returns revisited. Energy Economics, 82, 42-61.

Tiwari, A. K., Jena, S. K., Mitra, A., \& Yoon, S. M. (2018). Impact of oil price risk on sectoral equity markets: Implications on portfolio management. Energy Economics, 72, 120-134.

Wang, Y., \& Wu, C. (2012). Forecasting energy market volatility using GARCH models: Can multivariate models beat univariate models?. Energy Economics, 34(6), 21672181.

Wen, X., Bouri, E., \& Cheng, H. (2019). The Crude oil-stock market dependence and its determinants: Evidence from emerging economies. Emerging Markets Finance and Trade, 55(10), 2254-2274.

Westerlund, J., \& Sharma, S. S. (2019). Panel evidence on the ability of oil returns to predict stock returns in the G7 area. Energy Economics, 77, 3-12.

Xiao, J., Zhou, M., Wen, F., \& Wen, F. (2018). Asymmetric impacts of oil price uncertainty on Chinese stock returns under different market conditions: Evidence from oil volatility index. Energy Economics, 74, 777-786.

Yun, X., \& Yoon, S. M. (2019). Impact of oil price change on airline's stock price and volatility: Evidence from China and South Korea. Energy Economics, 78, 668-679.

Zakoian, J. M. (1994). Threshold heteroskedastic models. Journal of Economic Dynamics and control, 18(5), 931-955.

Zavadska, M., Morales, L., \& Coughlan, J. (2018). Brent crude oil prices volatility during major crises. Finance Research Letters.

Zhu, H., Guo, Y., You, W., \& Xu, Y. (2016). The heterogeneity dependence between crude oil price changes and industry stock market returns in China: Evidence from a quantile regression approach. Energy Economics, 55, 30-41. 